\title{
MANAJEMEN PERTUNJUKAN LAGU KARYA ANTONIO CARLOS JOBIM PADA RESITAL COLORFUL JAZZ
}

\author{
Ferry Susanto \\ FerrySusanto@isi.ac.id
}

\begin{abstract}
Abstrak
Penyajian resital bertujuan memberikan sumbangsih pengetahuan tentang lagu bossanova karya Antonio Carlos Jobim dan kolaborasi musik modern yang dipadukan dengan alat musik etnis yang dikemas dengan nuansa musik jazz yang sebelumnya belum pernah dilakukan. Manajemen tata kelola artistik panggung dibuat dengan menutupi seluruh dinding hingga lantainya dengan kain furing yang berwarna putih. Kemudian dengan beraneka lampu-lampu yang menyoroti seluruh sudut-sudut pada panggung tersebut dan berefek penuh warna yang sesuai dengan nama dari resital tersebut yakni Colorful Jazz. Proses pengumpulan data dalam penyajian resital ini dengan melakukan wawancara, pengamatan pada lagu karya Antonio Carlos Jobim, pengamatan pada proses latihan, mencari sumber pustaka baik dari internet maupun tinjauan pustaka yang mendukung, dan dokumentasi berupa foto dan audio visual. Dalam resital colorful jazz juga menggunakan seperangkat alat musik etnis seperti gamelan Jawa, gamelan Bali, taganing, talempong, suling Batak, dan rebana. Penulis dalam resital ini memainkan instrumen piano. Manajemen pertunjukan meliputi penyusunan kepanitiaan dan pembagian tugas. Penataan artistik meliputi konsep acara, pemilihan repertoar, pembuatan aransemen, latihan resital, pelaksanaan resital, dan evaluasi. Pelaksanaan resital ini berhasil memberikan pengalaman artistik yang berbeda dalam bidang penyajian seni musik jazz.
\end{abstract}

Kata kunci : manajemen, bossanova, resital, colorful jazz

\section{Pendahuluan}

Dalam pertunjukan resital ini manajemen sebagai basis dalam pengelolaan suatu organisasi seni pertunjukan memiliki kompetensi yang sangat krusial dalam menentukan laju dan arah pengembangan dari suatu seni pertunjukan. Secara umum dalam pengelolaan terasa sangat gampang, namun dalam peleksanaannya memerlukan penanganan yang sangat rumit, butuh perhatian khsusus serta lebih diutamakan pada pemngalaman empirik menjadi sumber dalam melaksanakan dan sekaligus menetapkan keberhasilan produksi karya seni secara proporsional.

Berikut ada dua hal yang terkait dengan tata artistik dalam resital colorful jazz, yaitu: (1) Panggung, dalam konsep artistik panggung pada resital, diusung konsep sederhana yaitu dengan menambahkan ornamen seperti kain furing yang berwarna putih yang dipasang pada seluruh panggung, mulai dari lantai sampai sisi background panggung. Kemudian ada beberapa lampu yang dipakai seperti lampu folow dan lampu panggung. Kemudian ada sedikit penambahan properti yaitu panggung kecil yang gunanya hanya dipakai untuk penempatan beberapa buah keyboard dan sebagai pelengkap, di tambahkan lilin pada sisi-sisi panggung sebagai cahaya; (2) Kostum, untuk kostum diberi tema elegant casual, yakni para pemain 
musik bebas mengenakan kemeja warna-warni sesuai tema resital yaitu colorful akan tetapi tetap pada kaidah kesopanan dalam sebuah pertunjukan resital.

Pada sesi pertama resitalis memakai jas cokelat muda dan kemeja putih. Pada sesi kedua penulis memakai kaos puth dipadukan dengan suspender merah. Pemain combo memakai jas hitam dan kemeja putih, pemain string wanita memakai gaun merah dan hitam, sedangkan pemain string laki-laki memakai warna kemeja yang berbeda yaitu biru, hitam, merah dan putih. Vokal (Tika) memakai gaun yang bercorak batik, vokal (Suci) memakai gaun berwarna orange, vokal (Dona) memakai gaun berwarna orange dan merah muda. Sedangkan kondakter memakai kemeja biru muda dan untuk pemain musik etnis memakai pakaian khas Jawa dan Bali.

Berikut dijelaskan beberapa pengertian tentang resital, musik bossanova, dan biografi dari Antonio Carlos Jobim, yakni sebagai berikut :

Mengenai istilah resital itu resital menurut Bapak Andre Idrawan (2013), resital adalah dari istilah sastra sehingga orang yang bercerita sendiri, monolog, khotbah, ceramah juga dinamakan sebuah resital. Istilah resital dalam bidang musik yakni penyajian yang menampilkan satu orang pemain musik tunggal atau lebih.

Kemudian menurut Koapaha (2013) selaku dosen di jurusan musik mengenai pengertian resital yang umum yaitu varian dari suatu konser musik umumnya dengan formasi musik kamar, seperti solo, duet, trio, kwartet dan sebagainya. Sekitar 30 tahun lalu istilah ini lebih ke suatu konser tunggal, misalnya konser piano tunggal pada seluruh pertunjukan, oboe dengan iringan piano dan lain sebagainya. Semakin kemari semakin tidak jelas istilah dari resital sudah hampir sama dengan konser.

Kemudian istilah Bossanova adalah musik campuran yang berasal dari ritme samba yang digabungkan dengan musik Eropa dan Amerika dari Debussy hingga jazz Amerika. Bossanova sendiri diciptakan oleh musisi jazz asal Brasil yang bernama Antonio Carlos Jobim dan Joao Gilberto serta Stan Getz dari Amerika pada tahun 1960. Karyanya yang paling terkenal adalah "The Girl from Ipanema".

Antonio Carlos Jobim atau dengan nama lahir (Antonio Carlos Brasileiro de Almeida Jobim) lahir di Rio de Janeiro, pada tanggal 25 Januari 1927 dan meninggal di Kota New York pada tanggal 8 Desember 1994 dalam usia 67 tahun. Jobim juga terkenal dengan panggilan Tom Jobim, adalah komponis, pembuat aransemen, penyanyi, pianis dari Brasil, dan salah satu legenda terbesar musik bossanova. Karya-karya Jobim telah dimainkan oleh berbagai musisi, termasuk Joao Gilberto, salah satu pelopor aliran bossanova bersama Jobim sendiri.

Ia menjadi makin populer setelah menciptakan lagu dengan judul "The Girl From Ipanema" dinyanyikan oleh Astrud Gilberto, yang menjadikannya terkenal di seluruh dunia. Bahkan Jobim termashur di seluruh dunia sebagai salah satu komponis yang paling berpengaruh pada abad ke-20.

Berdasarkan ide lagu The Girl From Ipanema tersebut, lalu digunakan sebagai materi melalui penyelenggarakan resital colorful jazz yang dikemas dalam irama bossanova. Karena lagu ini selain merupakan sangat populer di Brazil juga termasuk dikalangan komunitas, pencinta serta penikmat musik jazz yang ada di Yogyakarta dan sekitarnya.

Sementara genre bossanova sendiri masuk kedalam unsur musik latin jazz yaitu musik yang berasal dari negara Amerika Latin. Genre latin jazz memiliki banyak pola irama seperti samba, bossanova, salsa, mambo, dan sebagainya yang berawal dari irama pengiring tarian, 
kemudian menjadi lagu-lagu popular di sana. Irama samba yang awalnya adalah bentuk permainan perkusi pengiring tarian yang berasal dari Brazil, menjadi berkembang setelah dipadukan dengan unsur jazz dan dimainkan menggunakan alat musik melodis (S.D. Hendro, 2009:18).

Eksperimentasi pertunjukan musik diusung dengan tema "Colorful Jazz" dalam bentuk resital. Pertunjukan ini selain memainkan tiga lagu karya Antonio Carlos Jobim yang bernuansa bossanova juga membawakan lagu-lagu daerah Indonesia yang dikemas menjadi jazz dan berkolaborasi dengan berbagai macam instrumen musik etnis dari berbagai daerah dari Indonesia. Melalui begitu banyak dan beranekaragam kebudayaan di Indonesia, diharapkan dapat memberikan suatu pertunjukan yang didalamnya terdapat unsur rasa dan corak dari campuran musik modern Barat yang dikolaborasikan dengan musik etnis yang bernuansa jazz.

Aspek instrument dalam resital bertema ini, lebih banyak didominasi oleh piano. Terdapat tiga lagu karya Antonio Carlos Jobim yang berirama bossanova, yakni : The Girl From Ipanema, Corcovado, Wave, disertai beberapa aransemen lagu daerah seperti Caping Gunung, Janger, Medley Nusantara (Merombus-ombus, Ayam Den Lapeh, Paris Barantai), danSungai Kandilo.

Dari penyajian tersebut diharapkan dapat memberikan nuansa baru dalam pertunjukan musik jazz yang dipadukan dengan musik etnis kepada pendengar. Selain itu juga bisa menjadi referensi lagu-lagu pilihan dengan aransemen yang berbeda dalam sebuah resital musik.

The Girl From Ipanema, merupakan salah satu lagu karya Jobim yang paling terkenal di kalangan penikmat musik bossanova. Lagu ini tercipta ketika Jobim dan Frank Sinatra sedang berada di sebuah cafe yang terletak di pinggir pantai ipanema. Mereka melihat seorang gadis cantik sedang berjalan sendirian menyusuri pantai. Ketertarikan emosional sebagai laki-laki membuat mereka menaruh perhatian pada gadis tersebut. Dan, secara spontan mereka menciptakan sebuah lagu yang terinspirasi dari gadis itu, yaitu The Girl From Ipanema.

Lagu tersebut dimainkan dalam tangga nada F Mayor, dengan sukat 4/4, sementara bentuk aslinya adalah A A B A, ketika diaransemen ulang bentuk lagunya ditambah dengan intro. Kemudian diteruskan dengan tema lagu satu putaran penuh dengan iringan combo dan alat musik gesel lalu dilanjutkan dengan bagian improvisasi pada piano selama satu putaran penuh, lalu kembali ke tema awal dan diakhiri dengan coda.

Bagian introduksi, dimainkan oleh semua instrumen dalam combo, brass section dan string ansamble, sepanjang 8 birama dengan progresi akor I dan akor IV minor pada bagian intro. Dilanjutkan dengan bagian tema, setelah intro selama 8 birama kemudian vokal dimulai pada birama ke 9 yaitu bagian tema awal atau A sampai birama ke 16 yang terlihat pada gambar 1 dan 2. Kemudian diulang ke birama 9 hingga 16 yaitu A'. Dapat dilihat pada gambar 3 di mana terdapat jembatan sebelum masuk ke bagian B atau reff. 
Gambar 1

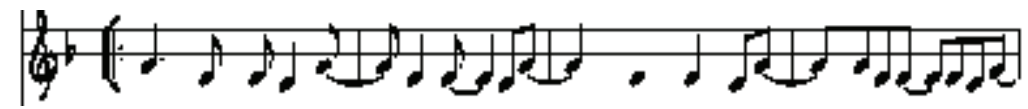

Gambar 2

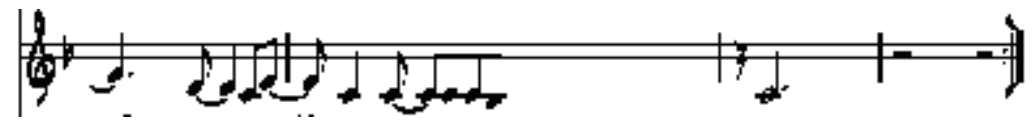

Gambar 3

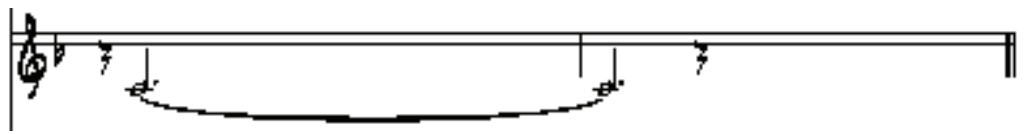

Coda

Pada bagian coda ada tutti birama. Berikut partitur pada instrumen combo.

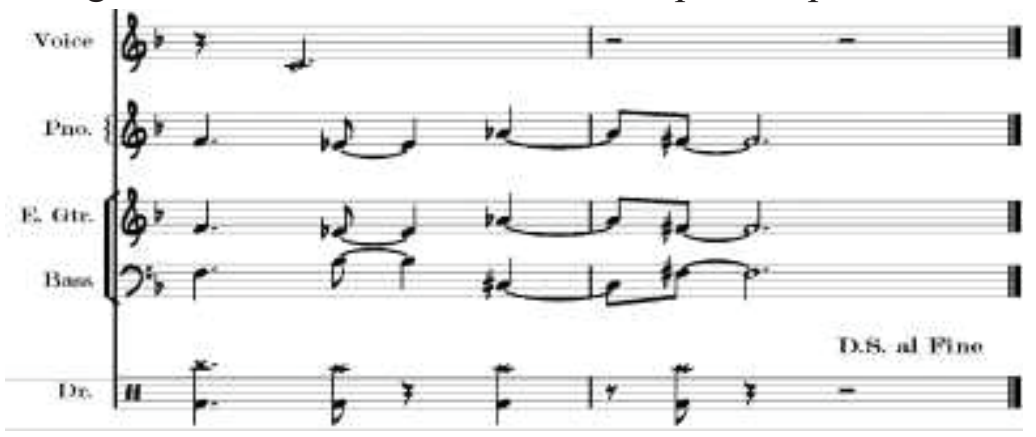

Selain itu, pertunjukan atau resital ini berbeda dengan pertunjukan-pertunjukan musik bossanova lainnya. Karena dalam pertunjukan musik ini juga berkolaborasi dengan musik orkestra. Yaitu diantaranya terdapat penggabungan antara instrumen combo, intrumen gesek, perkusi dan intrumen tiup.

Intrumen combo terdiri dari drum, bass, gitar, dan piano. Kemudian instrumen gesek terdiri dari beberapa biola 1 dan 2, cello, dan contrabass,. Lalu ditambah dengan intrumen perkusi seperti conga, maracas, dan chimes, dan instrumen tiup terdiri dari saxophone dan trumpet yang kemudian hari, keseluruhan musik tersebut menjadi satu kesatuan musik yang dinamakan orkestra atau ansambel besar.

Genre musik bossanova yang dipilih terutama sekali hanya memainkan lagu-lagu dari Antonio Carlos Jobim. Kemudian pada kolaborasi selanjutnya dari keseluruhan intrumen combo dan orkestra berkolaborasi dengan intrumen etnis dari berbagai lintas budaya di nusantara. Pada kolaborasi dengan intrumen-instrumen etnis maka karya yang dibawakan adalah lagu-lagu daerah Indonesia. Karena sangat disadar bahwa, kebhinekaan suku bangsa dan budayanya menjadikan Indonesia memiliki musik daerah yang tak terhitung banyaknya (Djohan, 2006:23). 


\section{Metode Penelitian}

Data penelitian kualitatif yang dibutuhkan dalam menyelenggarakan pertunjukan ini terdiri dari beberapa rangkaian proses yang harus dilakukan, seperti :

(a) Pengumpulan data dalam perancangan ini mencangkup: (1) wawancara, dengan narasumber dan pihak yang berkompeten atau ahli dibidang musik; (2) reinterpretasi terhadap lagu karya musik Antonio Carlos Jobim; (3) pengamatan dalam kegiatan latihan musiknya; (4) mengumpulkan sumber pustaka dan sumber internet yang terkait dengan musik; serta (5) pengumpulan dokumentasi audio visual seperti foto-foto dan rekaman film atau video dari kegiatan pementasan tersebut (Murgiyanto, 2016: 61).

(b) Manajemen Perencanaan Resital yaitu (1) Konsep, yang pertama dalam membuat pertunjukan yaitu memikirkan sebuah konsep pertunjukan yang diinginkan. Dalam hal ini penulis memilih konsep musik bossanova dan kolaborasi dengan musik etnis; (2) Tema, kemudian yang kedua adalah untuk menentukan tema apa yang akan dibuat dalam pertunjukan. Pada pertunjukan ini, penulis mengusung tema Colorful Jazz, karena dalam pertunjukannya penulis atau resitalis memainkan intrumen modern yang dikolaborasikan dengan berbagai intrumen etnis; (3) Repertoar, proses pemilihan repertoar ini merupakan hal yang tidak mudah dilakukan, karena repertoar yang dibawakan harus ditinjau dari banyak aspek.

Aspek-aspek tersebut antara lain, persoalan teknis, interpretasi, kelayakan tingkat kesulitan dijadikan referensi standar pertunjukan, dan kesesuaian lagu untuk mewakili tema yang ditentukan; (4) Arransemen, dalam proses aktif mengaransemen, dibutuhkan tahapan yang pertama yaitu mengenali jenis genre lagu, mencari referensi musiknya, membedah musiknya dari (intro, tema, interlude, reff, dan coda), dan memadupadankan bentuk arransemen kedalam lagu; (5) Pencarian Pemain Musik, pada proses kali ini biasanya adalah proses yang paling natural dilakukan, seperti karena sering bergaul dengan teman satu profesi dalam hal ini pemusik.

Biasanya bisa meminta teman agar membantu untuk menjadi pemain dalam pertunjukannya. Hal ini sudah menjadi sebuah hal yang biasa dilakukan dilingkungan pemusik; (6) Konsep artistik, dalam konsep artistik pada resital Colorful Jazz yaitu ingin menampilkan konsep tata panggung yang serba putih dengan tata cahaya yang menyoroti setiap sudut-sudut panggung sehingga terciptalah suasana yang penuh warna hal ini sesuai dengan tema resital tersebut.

(c) Manajemen Waktu Penyelenggaraan, pertunjukan ini dikemas layaknya konser-konser musik pada umumnya, dengan susunan acaranya sebagai berikut: (a) Pembukaan : Jam 19.30. 1) Sebelum memasuki gedung Auditorium ISI Yogyakarta, para penonton disuguhi sebuah pertunjukan kecil di depan pintu gerbang masuk, yaitu penampilan pantomim dari jurusan teater. Pertunjukan yang di kemas dalam bentuk slide (rekam video). 2) Setelah menikmati slide tersebut para penonton di persilahkan masuk ke dalam gedung Auditorium ISI Yogyakarta. (b)Sesi 1 : Jam 20.00.

(1) Lagu 1 Overture lagu ini sebagai musik pengantar atau pembuka resital; (2) Lagu ke 2 Corcovado merupakan salah satu lagu ciptaan Antonio Carlos Jobim dengan irama bosanova yang bertempo lambat. Dibawakan dengan format combo; (3) Lagu ke 3 The Girl From Ipanema ini adalah salah satu lagu karya Jobim yang terkenal di kalangan penikmat musik 
bossanova. Di bawakan dengan strategicombo dan string ansamble; (4) Lagu ke 4 , Wave dibawakan dalam format combo dan string ansamble. (c) Sesi 2 : Jam 20.40. (5) Lagu ke 5 Caping Gunung dalam lagu ini menceritakan tentang penantian seorang pejuang yang bosan akan janji-janji hidup dalam kemerdekaan, kesejahteraan, dan kemakmuran.Penulis membawakan dalam format lagu yang berbeda dari biasanya yaitu berkolaborasi dengan Komunitas Nunut Ngeyub dengan menggunakan instrumen gamelan Jawa; (6)Lagu ke 6 Janger lagu ini berasal dari Bali dan sangat terkenal di seluruh Indonesia bahkan di luar Negeri. Lagu ini menggambarkan suka cita remaja putra dan putri. Di bawakan dengan format combo, string ansamble dan seperangkat gamelan Bali; (7) Lagu ke 7 Medley Nusantara (Marombus-Ombus, Ayam Den Lapeh, Paris Barantai, Yamko Rambe Yamko) lagu ini di bawakan dengan format combo, string ansamble, brasssection dan berbagai instrumen etnis; (8) Lagu ke 8 Sungai Kandilo lagu yang terakhir yaitu "Sungai Kandilo". Sungai Kandilo adalah salah satu sungai yang terkenal di Kabupaten Paser karena terletak di pinggiran kota Tanah Grogot atau Tana Paser.

\section{Temuan dan Pembahasan}

Pada resital Colorful Jazz diperoleh sebuah hal baru dalam pengkolaborasian antara alat musik modern dengan berbagai jenis instrumen musik tradisional mulai dari gamelan Jawa hingga gamelan Bali yang diaransemen ulang serta dikemas dalam nuansa musik yang kaya harmoni.

Selain itu resital ini juga banyak melibatkan berbagai pihak yang terkait didalamnya, mulai dari rekan-rekan dari lintas Jurusan Karawitan, Etnomusikologi, Tari, Taeter, Seni Rupa, Media Rekam, lighting man, sound man dan seluruh pihak yang membantu mulai dari proses awal hingga akhir.

Hasil akhir resital tersebut banyak mendapatkan respon yang baik dari berbagai orang yang menyaksikan pada saat hari pertunjukan. Penulis juga mendapatkan pesan di media sosial menunjukkan bahwa, banyak yang mengatakan hal-hal positif terkait pertunjukan yang telah diselenggarakan dan menurut salah satu orang bahwa pertunjukan tersebut merupakan pertunjukan yang sangat menginspirasi.

Dalam hal ini sebuah kerja sama yang baik sangat dibutuhkan dalam mewujudkan sebuah pertunjukan yang berkualitas. Seperti melakukan proses latihan dengan personil yang komplit, adanya manajemen waktu yang baik mulai awal latihan sampai menjelang hari pertunjukannya, khususnya seluruh pemain musik sudah pasti harus bisa memenuhi standar pemain yang ideal dalam sebuah pertunjukan, dan hal ini juga tidak terlepas dari kekompakan atau kerja keras dari pihak crew resital tersebut.

Kemudian dalam kesuksesan suatu pertunjukan ini tidak terlepas dari gencarnya promosi melalui berbagai media, dalam resital ini melakukan promosi melalui media cetak dan media sosial yang ditujukan kepada seluruh kampus-kampus yang ada di Yogyakarta, komunitaskomunitas musik, dan seluruh masyarakat umum. 


\section{Kesimpulan}

Berdasarkan dari pertunjukan resital yang bertema Colorful Jazz ada beberapa hal yang dapat disimpulkan antara lain yaitu mulai dari penggarapan musiknya, tata artistik panggung dan kostum.

Dalam pelaksanaan resital ini telah berhasil menarik banyak penonton dan berhasil memberikan pengalaman terkait sebuah manajemen pertunjukan dengan tata kelola artistik yang menarik, misalnya seperti adanya kain furing berwarna putih yang menutupi seluruh sudut panggung, lalu adanya lampu-lampu yang menyoroti panggung tersebut sehingga efek dari lampu-lampu menjadi penuh warna yang diiringi dengan sajian musik bossanova yang dikolaborasikan dengan berbagai instrumen musik tradisional yang dikemas secara harmoni.

Kelengkapan dalam hal dokumentasi menggunakan media foto dan audio visual dalam pertunjukan resital tersebut. Dalam kajian karya ilmiah ini dapat menambah wawasan pengetahuan dan daftar referensi baru dalam sebuah manajemen pertunjukan musik dan tata kelola artistik.

\section{Kepustakaan}

Sandole, Adolp. 1972. Beginner's Method For Jazz Improvisation. Westeinde: 20 Music Books Import, DpringFields.

Saragih, Bill AR. 2000. Improvisasi Jazz Untuk Semua Alat Musik, Yayasan Pendidikan Musik \& Entertainment Indonesia

Jhon F, Szwed, 2008. Memahami Dan menikmati Jazz.Jakarta: PT. Gramedia Pustaka Utama. Koapaha, Royke B, 1999. Apresiasi Musik Jazz,Diktat,Yogyakarta.

Djohan. 2006. Terapi Musik, Galangpress: Yogyakarta

S.D, Hendro. 2009. Teknik Tercepat Belajar Bermain Melodi dan Improvisasi Gitar. Ruang Kata Imprint Kawan Pustaka.

Murgiyanto, Sal. 2016. Pertunjukan Budaya Dan Akal Sehat, Jakarta: IKJ (Institut Kesenian Jakarta).

http://wikipedia.org/wiki/Jazz_bossanova, 20 april 2012

http://“Bossanova”, Jazz apa bukan, Topekazhari, 19 September 2013

http://freedom institute » center for democracy, nationalism, and market economy studies, 11 agustus 2013

http://Antonio Carlos Jobim - Wikipedia bahasa Indonesia, ensiklopedia bebas, 19 September 2013

\section{Nara Sumber}

1. Dr. Andre Indrawan, M.Hum., M.Mus.,St. Selaku dosen pengampu Mata Kuliah Resital sekaligus sebagai Ketua Jurusan Musik FSP ISI Yogyakarta.

2. Drs. Royke B. Koapaha, M.Sn. selaku dosen pengampu Mata Kuliah Apresiasi Jazz. 